\title{
PENINGKATAN SKOR TEST BAHASA INGGRIS (TOEFL) MELALUI PELATIHAN SECARA INTENSIF
}

\author{
Sulistyo Seti Utami dan Bayu Pirmansyah \\ STIE Ahmad Dahlan Jakarta \\ sulistyo.setiutami@gmail.com
}

ABSTRAK

ABSTRACT
Artikel ini adalah bagian dari laporan implementasi kegiatan pelatihan intensif peningkatan skor test Bahasa Inggris. Kegiatan dilaksanakan karena: (1) kemampuan bahasa Inggris mahasiswa STIE Ahmad Dahlan Jakarta masih rendah yang berdampak rendahnya nilai pelajaran bahasa Inggris; (2) pembelajaran bahasa Inggris di kelas masih terbatas yang hanya satu kali pertemuan dalam seminggu; (3) kursus yang diberikan oleh STIE Ahmad Dahlan Jakarta kepada mahasiswa belum mampu meningkatkan nilai bahasa Inggris mahasiswa; (4) mahasiswa tidak mengikuti kursus di luar pembelajaran karena berbagai kendala dan keterbatasan yang dihadapinya; (5) belum pernah mengikuti pelatihan TOEFL secara intensif; dan (6) belum pernah mengikuti tes TOEFL. Metode pelaksanaan kegiatan adalah pembelian pelatihan pada mahasiswa melalui pemberian materi secara intensif. Hasil kegiatan menujukkan bahwa secara keseluruhan terjadi penurunan skor TOEFL setelah pelatihan, akibat dari tidak semua section dipelajari. Adanya peningkatan pada Section 2, karena hanya section 2 yang dipelajari. Rata-rata penilaian peserta terhadap instuktur baik dengan nilai rata-rata 8 (skala 1- 10).

Kata Kunci : pelatihan, TOEFL, kompetensi

This article is part of the implementation report of intensive training activities to improve English test score. The activities were carried out because: (1) the STIE Ahmad Dahlan Jakarta students' English proficiency is still low which has low impact on the value of English lessons; (2) English language teaching in the classroom is still limited which is only one meeting in a week; (3) the courses provided by STIE Ahmad Dahlan Jakarta to the students have not been able to increase the student's English score; (4) students do not take courses outside of learning because of the various constraints and limitations they face; (5) has never participated in intensive TOEFL training; and (6) have not taken the TOEFL test yet. The method of implementation of the activity is the purchase of training on students through intensive material delivery. The results show that overall the TOEFL score decreases after the training, as a result of not all sections being studied. There is an increase in Section 2, because only section 2 is studied. Average assessment of participants to the good structure with an average value of 8 (scale 1- 10).

Keywords: course, TOEFL, competences 
Masyarakat Indonesia saat ini dihadapkan pada kompetisi global, disamping kompetisi lokal (sesama warga Indonesia) terutama dalam memperoleh pekerjaan. Hal ini sebagai konsekuensi dari berlakunya berbagai perjanjian perdagangan bebas seperti Masyarakat Ekonomi Asean (MEA). Konsekuensi dari berlakunya perdagangan bebas diantaranya selain produk lokal memiliki kesemapatan yang luas untuk dijual di negara-negara Asia Tenggara, produk lokal juga akan berkompetisi di dalam negeri karena akan dibanjiri oleh produk dari negara-negara lain. Namun tidak hanya pada barang dan jasa, perdagangan bebas juga memberikan peluang yang luas baru arus tenaga kerja profesional. Dengan demikian Indonesia dituntut untuk memiliki skill yang lebih agar produk atau jasa dan tenaga kerja Indoenesia bisa bersaing di era MEA tersebut.

Nama faktanya, daya saing Indonesia masih rendah dan mengalami penurunan termasuk daya saing sumber daya manusia (SDM). Berdasarkan laporan International Institute for Management Development (IMD) 2016, sebagaimana dikutip www.republika.co.id, peringkat daya saing Indonesia turun enam peringkat dari peringkat ke-42 menjadi ke-48. Sementara berdasarkan penilaian World Economic Forum (WEF), sebagaimana dikutip www.cnnindonesia.com, peringkat daya saing Indonesia tahun ini [2016] turun dari posisi ke-37 pada tahun lalu menjadi ke-41. Sementara daya saing SDM Indonesia juga belum membanggakan. Indeks daya saing Indonesia 2016 memburuk dan turun ke posisi 41 dari 138 negara. Pada tahun sebelumnya, Indonesia berada di ranking ke 37. Adapun, indeks pengembangan sumber daya manusia pada 2015 lalu berada di posisi 110 dari 185 negara (www.bisnis.com $)$.

Dalam kerangka Masyarakat Ekonomi ASEAN (MEA), rendahnya daya saing tenaga kerja Indonesia ini justru menjadi ancaman yang merugikan Indonesia. Hal ini karena kebebasan mobilitas faktor produksi (modal dan tenaga kerja) merupakan hal yang dipersyaratkan dalam MEA. Dengan kata lain jika tidak bisa bersaing, Indonesia hanya akan menjadi pasar bagi negara-negara utama ASEAN lain, khususnya dalam konteks arus bebas tenaga kerja terampil/profesional (free flow of skilled labor) (Rahman, 2015).

Padahal sumber daya manusia merupakan faktor penting dalam meingkatkan daya saing bangsa. Pengertian sumber daya manusia tidak dalam arti jumlah tapi lebih pada kualitas. Inilah yang menjadi penjelas mengapa negara-negara dengan sumber daya manusia yang tersedia melimpah namun tidak mempunyak daya saing yang tinggi, karena kualitasnya masih rendah (Winoto, 2009). Oleh karena itu menjadi tanggung jawab banyak pihak bagaimana meningkatkan daya saing Indoneia melalui peningkatan sumber daya manusia, termasuk pemerintah dan perguruan tinggi. Perguruan tinggi memiliki 'PR' dan tanggung jawab yang besar dalam menciptakan lulusannya yang memiliki nilai kompetitif 
(daya saing) yang tinggi untuk menghadapi berbagai tantangan yang akan dihadapinya kelak.

Diantara rendahnya daya saing sumber daya manusia dan menjadi tanggung jawab perguruan tinggi adalah masalah penguasaan bahasa asing, terutama bahasa Inggris. Pengusaan bahasa Inggris sangat penting sebagai salah satu upaya dalam meningkatkan daya saing, baik dalam dunia kerja maupun dunia akademik. Dalam dunia kerja, penguasaan bahasa asing merupakan poin tambah bahkan menjadi syarat utama diterimanya bekerja di perusahaan, terutama tentu saja di luar negeri. Di dunia akademik, masih banyak yang tidak masuk perguruan tinggi atau tidak lulus beasiswa karena nilai bahasa Inggris yang masih di bawah standar. Berdasarkan Indonesia International Education Foundation (IIEF) sebagaimana diberitakan tempo.co, kendala utama dalam memperoleh beasiswa adalah karena masih rendahnya skor Test of English as a Foreign Language Intitutional Test Program atau TOEFL ITP sebagai salah satu syarat beasiswa ke luar negeri. Skor pemohon beasiswa masih di bawah batas minimal yang persyaratkan, yaitu 500, rata-rata skor pelamar adalah hanya 470 .

Penguasaa bahasa Inggris terutama tingkat skor TOEFL penting tidak hanya untuk mendapatkan beasiswa atau kuliah di perguruan tinggi tertentu saja, namun juga terkadang menjadi persyaratan untuk melamar pekerjaan dan naik jabatan. Husni dan Susilowati (2011) mengkonfirmasi bahwa kemampuan berbahasa Inggris mempunyai arti yang sangat penting, karena sangat diperhitungkan dalam dunia pendidikan maupun dunia kerja, sehingga banyak yang memperdalam kemampuan berbahasa Inggris.

Untuk itu upaya dalam rangka meningkatkan nilai skor TOEFL penting dilakukan untuk membekali masyarakat dalam menghadapi dunia global dengan tingkat kompetisi yang sangat ketat. Diantara elemen masyarakat yang harus mendapat perhatian khusus dalam peningkatan penguasaan bahasa asing adalah mahasiswa. Karena mahasiswa akan menghadapi banyak kemungkinan setelah lulus kuliah, bekerja atau melanjutkan kuliah ke jenjang yang lebih tinggi, dan itu membutuhkan penguasaan bahasa Inggris. Atas dasar itulah menjadi urgent upaya pelatihan peningkatan skor TOEFL bagi mahasiswa.

Sekolah Tinggi Ilmu Ekonomi Ahmad Dahlan Jakarta (STIE AD) merupakan perguruan tinggi yang memiliki visi menciptakan lulusan yang memiliki daya saing tinggi memiliki tanggung jawab untuk mencapai visi tersebut. Dalam mencapai visinyat, STIE AD harus membekali mahasiswanya dengan berbagai keterampailan seperti penguasaan bahasa asing dalam bidang akademik. Pembekalan bahasa Inggris bagi mahasiswa STIE AD penting dilakukan mengingat penguasaan bahasa Inggris mereka rata-rata masih di bawah standar, 60 skala 100 berdasarkan nilai bahasa Inggris yang diperoleh. Ditambah lagi mereka masih asing dengan TOEFL. Sebagian besar dari mereka belum pernah mengikuti tes TOEFL bahkan ada yang tidak tahu. 
Pemberian materi atau pelatihan TOEFL bagi mahasiswa akan sangat berguna karena akan menunjang kemampuan komunikasi dalam bahawa Inggris terutama dalam tulisan. Karena dalam TOEFL memuat materi Listening, Structure, dan Reading. Dengan Listening, mahasiswa (peserta) dapat memiliki kemampuan memahami teks-teks yang bersifat audio (suara). Sedangkan pada materi Structure mahasiswa akan mampu memahami bahasa Inggris yang baik dan benar terutama dalam tulisan. Sementara pada materi Reading, mahasiswa akan mampu memahami bahasa inggris yang lebih luas, karena dalam materi Reading terdapat pembahasan atau tema yang beragam.

Berdasarkan latar belakang di atas, juga berdasarkan pengamalan memberikan materi bahasa Inggris di kelas, masalah yang dihadapi oleh mahasiswa STIE Ahmad Dahlan Jakarta dalam penguasaan bahasa Inggris adalah sebagai berikut:

1. Kemampuan bahasa Inggris mahasiswa STIE Ahmad Dahlan Jakarta masih rendah;

2. Rendahnya kemampuan bahasa Inggris mahasiswa STIE Ahmad Dahlan Jakarta berdampak pada rendahnya nilai pelajaran bahasa Inggris;

3. Pembelajaran (materi kuliah) bahasa Inggris di kelas masih terbatas, hanya satu kali pertemuan dalam seminggu;

4. Kursus yang diberikan oleh STIE Ahmad Dahlan Jakarta kepada mahasiswa belum mampu meningkatkan nilai bahasa Inggris mahasiswa;

5. Mahasiswa tidak memiliki peluang untuk belajar bahasa Inggris (kursus) di luar karena berbagai kendala dan keterbatasan;

6. Belum pernah mengikuti pelatihan TOEFL secara intensif;

7. Belum pernah mengikuti tes TOEFL

Pengabdian masyarakat ini dilakukan dengan memberikan bimbingan/pelatihan secara intensif kepada peserta terkait dengan peningkatan skor TOEFL. Metode yang digunakan adalah metode kelas, yaitu memberikan materi di dalam kelas yang telah disediakan.

Materi TOEFL terdiri dari tiga sesi yaitu, listening, structure, dan reading. Perioritas pemberian materi apakah listening, structure, dan reading tergantung dari hasil pretest. jika misalnya nilai listening yang rendah, maka pemberian materi akan diperioritaskan pada listening. Prioritas pemberian materi juga bisa dilakukan berdasarkan persepsi atau keinginan peserta. Mana yang lebih sulit dan penting menurut persepsi peserta untuk diberikan materi maka itu yang dipilih.

Proses kegiatan pengabdian pada masyarakat ini dapat dilihat pada gambar sebagai berikut. 


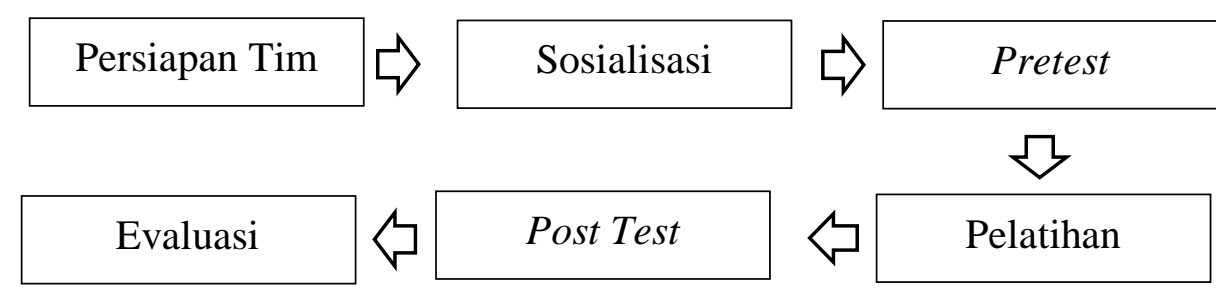

Gambar 1. Proses Pelaksanan Kegiatan

Tahapan pertama dalam melaksanakan pengabdian masyarakat ini adalah melakukan sosialisasi kepada calon peserta (mahasiswa) bahwa akan diadakan program pelatihan peningkatan skor TOEFL. Sosialisasi dilakukan melalui pengumuman di mading dengan leaflet, SMS Blust, Group WA, Facebook, dan media lain yang memungkinkan. Peserta pelatihan adalah mereka yang telah mendaftar sebagai peserta pelatihan, dengan syarat mahasiswa STIE Ahmad Dahlan Jakarta dari berbagai jurusan dan angkatan. Pendaftaran peserta akan ditutup setelah memenuhi kuota yaitu sebanyak 30 peserta.

Tahapan kedua adalah melaksanakan kegiatan. Kegiatan dilakukan diawali dengan pre test dilanjutkan dengan pembekalan materi beserta trik dan tips dalam menjawab soal TOEFL, dan simulasi pengisian soal. Pret test dilakukan untuk mengetahui gambaran atau skor TOEFL awal peserta sekaligus untuk mengetahui kemampuan peserta dalam mengerjakan soal. Selanjutnya diberikan materi tentang TOEFL disertai dengan simulasi dan dilanjutkan dengan tes akhir. Skor tes akhir ini dijadikan patokan apakah ada peningkatan dari skor sebelumnya atau tidak. Untuk mengetahui ada atau tidaknya peningkatan skor TOEFL dapat dilihat dari skor rata sebelum dan setelah pelatihan.

Adapun cara menghitung skor TOEFL dapat dilakukan sebagaimana tahap-tahap berikut ini Fauzy, et al., (2013) dalam Marbun, et al., (2016):

1. Jumlahkan skor hasil konversi

Jumlah $=$ skor listening + skor structure and written expression + skor reading

2. Bagi hasil penjumlahan di atas dengan 3 (tiga)

Jumlah = Jumlah : 3

3. Kalikan hasil pembagian dengan 10

Skor TOEFL $=$ hasil pembagian $* 10$

Tahap selanjutnya adalah jika pelaksanan ini berhasil dengan indikator ada perbedaan skor sebelum dan sesudah pelatihan, dimana skor pelatihan lebih tinggi dari sebelumnya, maka pelatihan ini selesai dilaksanakan. Pada tahap ini juga dilakukan evaluasi tentang metode pengajaran dan kemampuan tutor dalam memberikan materi melalui penyebaran kuesioner (pertanyaan) kepada peserta. Namun jika pelaksanaan pengabdian ini tidak berhasil yang ditandai dengan perbedaan skor TOEFL sebelum dan setelah pelatihan, dimana skor setelah pelatihan lebih rendah atau sama dengan setelah pelatihan maka dilakukan evaluasi dan 
dilanjutkan dengan pemberian materi dan simulasi lagi. Begitu seterusnya sampai dengan berhasil sesuai dengan target.

Pelatihan ini masih menggunakan paper-based test, karena menurut Priyasudiardja (2014), persyaratan tes TOEFL di beberapa perguruan tinggi di Indonesia masih menggunakan paper-based test, terutama TOEFL ITP (Institutional Testing Program) yang dikelola oleh ETS (English Testing System).

Dengan struktur materi demikian, target capaian kegiatan sebagaimana tersaji dalam Tabel 1. di bawah ini.

Tabel 1. Target Capaian Luaran

\begin{tabular}{|l|l|}
\hline \multicolumn{1}{|c|}{ Jenis Luaran } & \multicolumn{1}{c|}{ Indikator Luaran } \\
\hline $\begin{array}{l}\text { Pemahaman tes bahasa asing } \\
\text { terutama TOEFL bagi peserta }\end{array}$ & $\begin{array}{l}\text { Peserta bisa menjelaskan } \\
\text { tentang berbagai tes bahasa } \\
\text { asing terutama bahasa TOEFL }\end{array}$ \\
\hline $\begin{array}{l}\text { Pemahaman tentang trik dan } \\
\text { strategi dalam menjawab soal } \\
\text { TOEFL }\end{array}$ & $\begin{array}{l}\text { Peserta mampu menjawab soal } \\
\text { TOEFL dengan benar }\end{array}$ \\
\hline $\begin{array}{l}\text { Peningkatan skor TOEFL } \\
\text { peserta }\end{array}$ & $\begin{array}{l}\text { Adanya peningkatan skor } \\
\text { TOEFL }\end{array}$ \\
\hline
\end{tabular}

Metode yang digunakan dalam tahapan penyediaan data penelitian ini menggunakan metode simak. Metode simak (Mahsun, 2007: 242) adalah metode yang digunakan dalam penyediaan data dengan cara peneliti melakukan penyimakan penggunaan bahasa. Metode ini memiliki teknik dasar yaitu teknik sadap. Dalam praktik penelitian, penyimakan dilakukan dengan menyadap penggunaan bahasa dari informan.

Sosialisasi kegiatan dilakukan sebulan sebelum pelaksanaan pelatihan dimulai. Sosialisasi dilakukan pada bulan Mei 2017 melalui informasi berantai (WhatsApp), mouth to mouth, serta penempelan poster di mading kampus. Hasil dari sosialisasi kegiatan terdapat 32 (tiga puluh dua) orang mahasiswa yang mendaftar untuk mengikuti kegiatan pelatihan yang berasal dari berbagai jurusan (akuntansi, manajemen, dan keuangan perbankan). Pada dasarnya tidak ada persyaratan khusus untuk mengikuti pelatihan ini. Kecuali mahasiswa aktif STIE Ahmad Dahlan Jakarta yang memiliki keinginan yang kuat untuk meningkatkan nilai atau skor TOEFL-nya. Hal ini memberikan kesempatan kepada seluruh mahasiswa STIE Ahmad Dahlan Jakarta untuk mengikuti pelatihan TOEFL. Hanya saja sumber daya kegiatan seperti instruktur tebatas. Sehingga agar pelatihan ini efektif, mampu mencapai tujaun yang diinginkan, maka perserta dibatasi 20 - 30 orang. Berdasarkan jumlah peserta yang mendaftar penyelenggara berusaha untuk mengkomodir seluruh peserta yang mendaftar. Dengan harapan memberikan kesempatan kepada mahaisswa STIE Ahamad Dahlan Jakarta untuk mengikuti pelatihan TOEFL.Untuk mempermudah pemberian informasi, peserta yang medaftar 
dibuatkan grup WhatApps. Grup tersebut juga berfungsi untuk berdiskusi tentang pelatihan TOEFL.

Untuk mengetahui kemampuan awal peserta dalam menjawab setiap soal, peserta wajib mengikutipre test. Kegiatan ini juga untuk melihat perubahan atau perkembangan skor TOEFL setelah pelatihan nanti. Dari 32 orang yang mendaftar untuk mengikuti pelatihan TOEFL, hanya 30 orang yang bisa mengikuti pre test. Pre test dilakukan secara full, yaitu semua soal TOEFL diujikan mulai dari section 1 sampai dengan section 2 yang dilakukan sebagaimana tes TOEFL pada umumnya dengan waktu yang telah dilakukan. Berikut adalah peserta pre test sesuai dengan jurusan.

Peserta yang mengikuti pre test didominasi oleh mahasiswa jurusan S1 manajemen, yaitu sebanyak 75\%. Sedangkan sisanya adalah berasal dari jurusan S1 Manajemen 13\%, D3 Keuangan Perbankan (KP) 9\%, dan D3 Akuntansi 3\%. Berikut adalah hasil skor pre test dari 30 peserta yang mengikuti pre test.

Tabel 2. Skor Hasil Pre test

\begin{tabular}{lrrrr}
\hline & Section 1 & Section 2 & Section 3 & Skor \\
\hline Rata-Rata & 36,8 & 36,4 & 44,0 & 390,5 \\
Nilai Tertinggi & 43 & 63 & 57 & 503 \\
Nilai Terendah & 30 & 26 & 35 & 317 \\
Interval & 13 & 37 & 22 & 186 \\
Standar Deviasi & 3,9 & 8,8 & 5,5 & 43,9 \\
\hline Sumber: data diolah, 2017 & & & &
\end{tabular}

Berdasarkan Tabel di atas, skor TOEFL peserta menunjukkan rata-rata 390,5. Hal ini mengindikasikan skor TOEFL masih jauh dari standar, yaitu 500. Hanya ada dua peserta saja yang memiliki nilai di atas atau skor di atas 500 sekaligus sebagai nilai tertinggi. Sementara nilai terendah adalah 186. Jika dilihat per section-nya, nilai tertinggi berada pada section 4 (reading) dan terendah pada section 2 hampir sama dengan section 1 (listening).

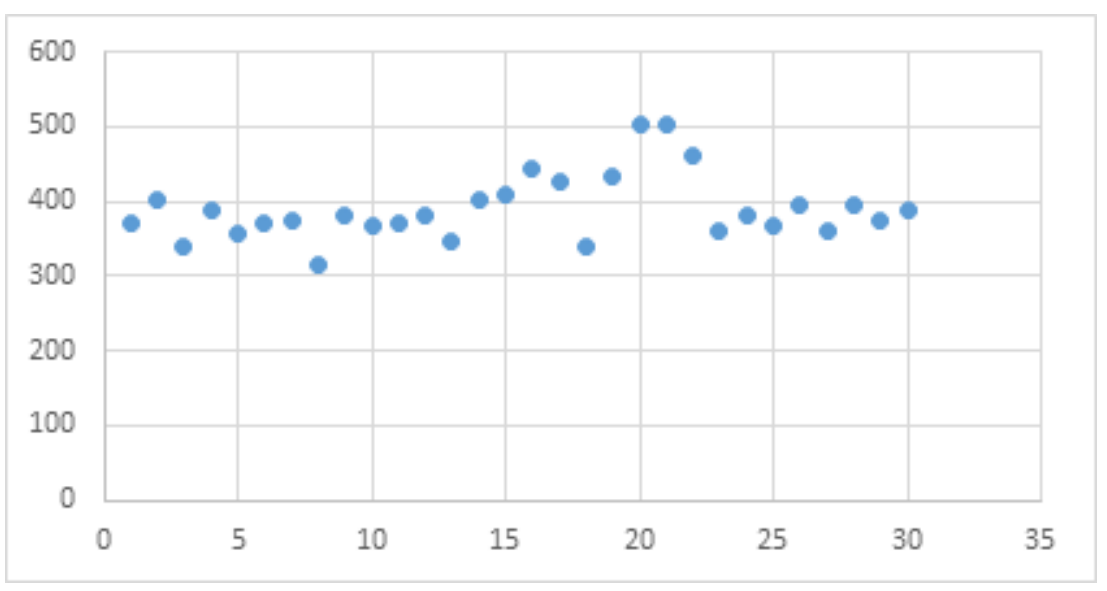

Gambar 2. Skor Pre test 
Sesuai dengan rencana pelatihan, dikarenakan keterbatasan instrukur, pelatihan ini akan diprioritaskan section yang memiliki skor terendah, yaitu section 2 (Structure \& Written Expression). Pelatihan dilakukan selama enam kali pertemuan dengan intruktur pelaksana pengabdian yang juga dosen bahasa Inggris di STIE Ahmad Dahlan Jakarta.

Rendahnya skor peserta pada section ini karena untuk menulis yang baik dan benar membutuhkan keterampilan khusus. Menurut Amilia (2018), keterampilan menulis disebut sebagai keterampilan yang membutuhkan kompetensi dan keterampilan berbahasa yang kompleks. Setidaknya, keterampilan menulis membutuhkan keterampilan membaca dan mendengarkan. Keterampilan menulis merupakan keterampilan produktif, sama seperti berbicara. Namun, keterampilan menulis dianggap lebih sulit dari keterampilan berbicara. Hal ini disebabkan aturan yang kompleks dalam kegiatan menulis.

Meskipun peserta yang mendaptar pelatihan TOEFL berjumlah 32 orang dan yang mengikuti pre test sebanyak 30 orang, namun yang mengikuti pelatihan hanya berjumlah 15 orang. Hal ini diantaranya diakibatkan karena terjadi kesamaan jadwal kuliah dengan waktu pelatihan. Sehigga antusiasme peserta (jika dilihat dari jumlah yang mendaftar) tidak diikuti dengan pelaksanaan pelatihan. Apalagi pelatihan ini tidak diwajibkan kepada peserta. Meskipun demikian diharapkan peserta sungguh-sungguh untuk mengikuti pelatihan ini.

Pelatihan ini dilakukan pada hari Rabu, Jum'at, atau Sabtu satu kali dalam satu minggu tergantung pada kesediaan waktu peserta dan instruktur. Meskipun demikian pelatihan dilakukan secara insentif dan konsisten satu minggu sekali.

Materi yang diberikan dibagi kedalam tiga kategori, yaitu pemberian materi TOEFL secara umum, pembahasan soal TOEFL, dan simulasi. Sebagaimana diketahui, pada section ini terdapat 40 soal yang diujikan. Terdapat dua tipe pada soal section 2 ini, yaitu soal berupa structure (Sentence Completion) dan Written Expression (Error Identification). Kedua hal ini merupakan 2 jenis soal yang berbeda. Pada bagian structure kita diwajibkan memilih jawaban yang tepat pada soal pilihan ganda atau multiple choice. Pada bagian structure completion kita diperintahkan agar kita dapat memilih grammar yang lebih banyak mengenai tenses, preposition, dan ejaan yang disepurnakan dalam baahsa Inggris.

Sedangkan pada bagian written expression diharuskan untuk mengisi memilih jawaban yang salah. Atau pilihan yang tidak tepat. Jika misalnya saja kita melihat kalimat. Written Expression merupakan soal yang membutuhkan pengetahuan anda terhadap kalimat yang terdapat dalam soal. Prosedur umum mengerjakan pertanyaan bentuk written expression adalah dengan melihat kata yang digarisbawahi (memilih secara langsung yang menurut kita kata tersebut salah), Jika tidak dapat memilih, maka bacalah secara komplit kalimat dalam soal. 
Meskipun section 2 yang diprioritaskan section 3 juga sempat dibahas dalam pelatihan ini. Section 3 dipilih dibandingkan dengan section 1 yang rata-rata nilai pre test-nya rendah, karena keterbatasan sarana. Karena section 1 membutuhkan sound yang representatif.

Setelah dilaksanakan pre test dan pelaksanaan inti kegiatan (pelatihan), dilakukan uji post test. Kegiatan ini merupakan salah satu rangkaian pelatihan TOEFL yang akan menentukan berhasil atau tidaknya pelatihan ini. Keberhasilan pelatihan TOEFL ini ditandai dengan adanya peningkatan skor TOEFL peserta dari tes sebelumnya, yaitu pre test. Apabila adanya peningkatan, hasil post test lebih besar dari pre test, maka pelatihan ini telah berhasil. Sebaliknya jika rata-rata peserta mengalami penurunan atau tetap hasil post test-nya maka dapat dikatakan pelatihan ini belum berhasil.

Karena pada section 1 tidak dibahas dalam pelatihan TOEFL ini maka section 1 tidak diujikan dalam post test ini. Meskipun demikian tetap dimasukan sebagai kemponen penilaian post test secara keseluruhan. Berikut adalah skor hasil post test pelatihan TOEFL dibandingkan dengan hasil pre test.

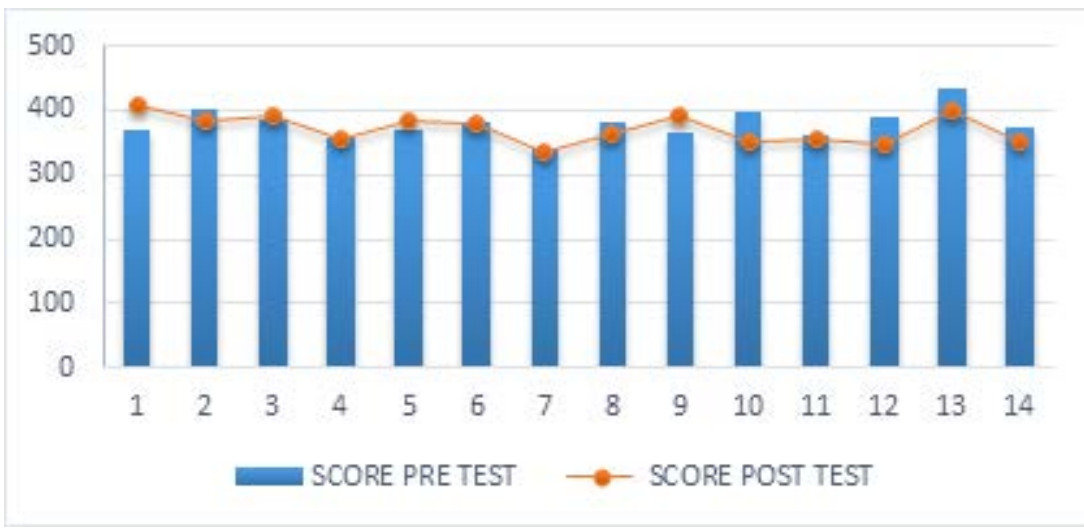

Sumber: data diolah, 2017

Gambar 3. Skor Pre test dan Post test

Secara keseluruhan, dari 15 peserta yang mengikuti pelatihan dan post test, hanya empat orang yang nilai TOEFL nya mengalami peningkatan. Tujuh oran mengalami penurunan, dan sebanyak empat orang yang skor TOEFL-nya tetap. Banyaknya peserta yang mengalami penurunan skor TOEFL akibat dari tidak semua section dibahas dipelatihan ini. hal ini tidak berpengaruh pada skor TOEFL dan dimungkinkan bisa mengalami penurunan.

Berbeda dengan hasil secara keseluruhan, nilai section 2 yang dibahas dalam pelatihan banyak yang mengalami penigkatan. Berikut adalah hasil pre test dan post test section 2 . 


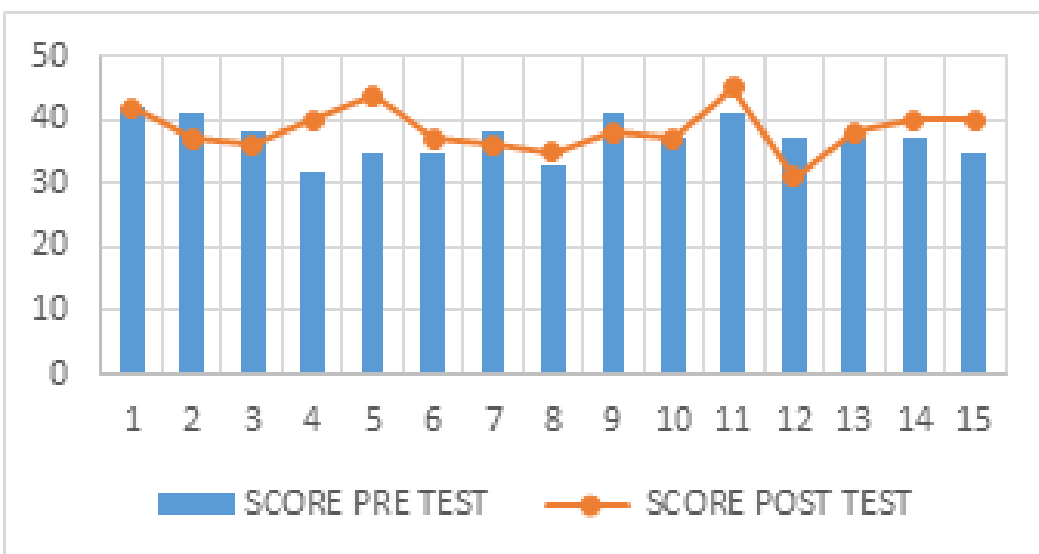

Sumber: data diolah, 2017

Gambar 4. Skor Pre test dan Post test section 2

Dari 15 peserta yang mengikuti pelatihan dan post test, pada section 2 terdapat Sembilan orang yang mengalami kenaikan, empat orang mengalami penurunan dan sebanyak dua orang yang mengalami penurunan pada post test section 2 ini dibandingkan dengan hasil pre test yang dilakukan sebelumnya. Sehingga dapat dikatakan pelatihan ini telah berhasil dalam meningkatkan skor TOEFL peserta pada section 2 .

Pada akhirnya, setelah pelaksanaan kegiatan selesai dilaksanakan, kegiatan evaluasi perlu dilakukan. Evaluasi dilakukan untuk mengetahui seberapa besar penilaian peserta terhadap instruktur. Penilaian ini mungkin juga dapat dikaitkan dengan hasil skor TOEFL. Apabila penilaian peserta terhadap instrukur baik, maka seharusnya nilai skor TOEFL juga akan baik, karena dari sisi instruktur tidak ada masalah dalam memberikan materi. Sebaliknya jika penilaian peserta terhadap instruktur jelek maka hasil atau sekor TOEFL juga jelek. Namun apabila penilaiannya baik namun hasil skornya kurang memuaskan maka permasalahan berada pada peserta bukan pada instruktur.

Komponen yang dinilai pada penilaian instruktur ini meliputi: Ketepatan waktu, cara penyampaian materi, kesesuaian materi dengan tujuan pelatihan, penguasaan materi, interakasi dengan peserta, kejelasan penyampaian materi, dan pengendalian suasana. Dengan menggunakan skal 1 - 10, dimana semakin mendekati 1 adalah semakin buruk atau semakin tidak puas, dan jika semakin mendekati 10 semakin baik atau semakin puas. Indikator evaluasi meliputi: ketepatan waktu, cara penyampaian materi, kesesuaian materi dengan tujuan pelatihan, penguasaan materi, interaksi dengan peserta, kejelasan penyampaian materi, pengendalian suasana, dan saran.

SIMPULAN

Berdasarkan hasil pengabdian yang telah dilakukan sebagaimana dipaparkan pada bab sebelumnya, kegiatan ini dapat disimpulkan sebagaimana berikut. (1) secara keseluruhan terjadi penurunan skor TOEFL setelah pelatihan, akibat dari tidak semua section dipelajari; (2) terjadi peningkatan pada Section 2, karena hanya section 2 yang dipelajari secara detail; dan (3) Rata-rata 
penilaian peserta terhadap instuktur baik dengan nilai rata-rata 8 (skala 1- 10). Saran tindak lanjut atas kegiatan pelatihan ini adalah: (1) perlu dilakukan pelatihan secara konprehensif (section 1 - 3); dan (2) Peningkatan motivasi peserta perlu ditingkatkan agar mengikuti pelatihan dengan sungguh-sungguh.

\section{DAFTAR PUSTAKA}

Amilia, F., 2018. Pemahaman Dan Habituasi Untuk Membangun Kompetensi Menulis Praktis Dan Ilmiah. Lingua Franca: Jurnal Bahasa, Sastra, dan Pengajarannya P-ISSN: 23025778 Vol 6 No. 1 Februari 2018 Hal 22 - 31. Sumber: https://goo.gl/zCQ9g9 diakses 2 Agustus 2018

Husni, M., dan Susilowati, E, 2011. Sistem E-Learning Dalam Pembelajaran IBT Toefl (Internet Base Test Of English As A Foreign Language) Menggunakan Media Voip (Voice Over Internet Protocol). jsh Jurnal Sosial Humaniora, Vol 4 No.2, November 2011. Hal. 196-212. Sumber: $\quad$ https://goo.gl/iqxFzL diakses 2 Agustus 2018

Marbun, et al., 2016. Pembuatan Aplikasi TOEFL sebagai Media Pelatihan Bahasa Inggris Berbasis Web. Jurnal Teknologi dan Sistem Komputer, Vol. 4, No. 1, Januari 2016 e-ISSN: 2338-0403. Sumber: https://goo.gl/WMMRKZ diakses 2 Agustus 2018
Priyasudiardja, Y., 2014. Strategi Jitu Meraih Skor TOEFL 600 dalam 1 Bulan. Bandung: Mizan Pustaka

Rahman, 2015. Daya Saing Tenaga Kerja Indonesia Dalam Menghadapi Masyarakat Ekonomi Asean (MEA). eJournal Ilmu Hubungan Internasional, 2015, 3 (1): 117-130

Winoto, 2009. Daya Saing Sumber Daya Manusia Indonesia (Menghadapi ASEAN-CHINA Free Trade Area). Jurnal Ilmiah Manajemen Bisnis, Vol. 9 No. 3 September 2009. Hal. 155-160

www.cnnindonesia.com. 2016. World Economic Forum Pangkas 4 Level Daya Saing Indonesia. sumber: https://goo.gl/te2VPz diakses 11 April 2017

www.kabar24bisnis.com. Daya Saing SDM Rendah, Pendidikan Tinggi Perlu Direvitalisasi. sumber: https://goo.gl/6aJtvF diakses 11 April 2017

www.republika.co.id. 2016. Peringkat Daya Saing Ekonomi Indonesia Melorot. sumber: https://goo.gl/xYTt2U. diakses 11 April 2017 